\title{
MEKANISME PERLINDUNGAN HUKUM HAM TERHADAP PEREMPUAN DAN ANAK
}

\author{
Oleh: \\ A. Valentino Sinaga ${ }^{1}$, Ronny A. Maramis ${ }^{2}$, Emma V. T. Senewe \\ $1,2,{ }^{3}$ Universitas Sam Ratulangi \\ 1 valentinosinaga422@gmail.com
}

\begin{abstract}
ABSTRAK: Penelitian bertujuan untuk mengetahui mekanisme perlindungan hak asasi manusia terhadap perempuan dan anak sebagai kelompok rentan; kebijakan perlindungan; dan penanggulangan terhadap perempuan dan anak sebagai kelompok rentan dari kekerasan dan korban kejahatan. Penelitian menggunakan pendekatan penelitian yuridis normatif yang bersifat kualitatif. Penelitian dilakukan melalu studi kepustakaan (library research). Penelitian lapangan (field research) adalah penelitian yang dilakukan dengan mengumpulkan data-data langsung dari pihak yang berkompeten. Data dianalisis melalui dua tahap, pertama menggunakan strategi analisis umum yang disebut strategi menggandakan proposisi teoritis (relying on theoretical prepositions), tahap kedua menggunakan teknik analisis yang disebut dengan explanation building. Hasil penelitian menunjukkan bahwa pemerintah telah membuat peraturan perundangundangan nasional yang bertujuan melindungi kelompok rentan tertentu selain perempuan dan anak, termasuk didalamnya mekanisme pemajuan dan perlindungan hak asasi manusia serta adanya Rencana Aksi Nasional Hak Asasi Manusia (RAN-HAM). Peraturan-peraturan tersebut selanjutnya dijalankan oleh pemerintah daerah dalam hal ini Dinas Pemberdayaan Perempuan dan Perlindungan Anak Daerah melalui Unit Pelaksana Teknis Daerah Provinsi Sulawesi Utara dalam mekanisme perlindungan hukum dengan menjabarkan dalam aturan-aturan daerah serta bekerjasama dengan berbagai pihak terkait. Dalam praktiknya, antara lembaga-lembaga Masyarakat Pemerhati Perempuan dan Anak belum bersinergi secara maksimal dengan Dinas Pemberdayaan Perempuan dan perlindungan Anak Daerah Provinsi Sulawesi Utara. Selain itu belum ada MoU antara stakeholder terkait dengan Dinas Pemberdayaan Perempuan dan Perlindungan Anak Daerah Provinsi Sulawesi Utara. Hasil penelitian dapat disimpulkan bahwa terdapat berbagai regulasi tentang perlindungan perempuan dan anak yang menjadi acuan, namun belum ada hukum yang secara khusus mengatur bentuk pencegahan dan penanggulangan tindak kekerasan terhadap perempuan dan anak. Hukum positif yang berlaku untuk menuntut kejahatan dan pelanggaran di sektor publik adalah KUHP. Diantaranya kasus bullyng antara pelaku anak dan korban anak yang tejadi dibeberapa kabupaten/kota yang viral akhir-akhir ini, sampai saat ini belum ada kepastian hukuman dalam bentuk edukasi yang jelas yang tertuang dalam UndangUndang Perlindungan Anak.
\end{abstract}

KATA KUNCI: Mekanisme, Perlindungan Hukum HAM, Perempuan dan Anak

ABSTRACT: The research aims to determine the mechanisms of human rights protection for women and children as a vulnerable group; protection policies; and countermeasures against women and children as vulnerable groups from violence and victims of crime. The research uses a normative juridical research approach that is qualitative. The research was conducted through library research. Field research is research conducted by collecting data directly from competent parties. The data is analyzed through two stages, the first using a general analysis strategy called relying on theoretical prepositions, the second stage uses an analysis technique called explanation building. The results showed that the government has made national legislation aimed at 
protecting certain vulnerable groups other than women and children, including the mechanism of promotion and protection of human rights and the existence of a National Action Plan for Human Rights (RAN-HAM). The regulations are then carried out by the local government in this case the Office of Women Empowerment and Regional Child Protection through the Regional Technical Implementation Unit of North Sulawesi Province in the mechanism of legal protection by describing in the regional rules and cooperating with various related parties. In practice, between the institutions of the Society of Women and Children Observers has not synergized to the maximum with the Office of Women Empowerment and Child Protection of North Sulawesi Province. In addition, there is no MoU among stakeholders related to the Office of Women Empowerment and Child Protection of North Sulawesi Province. The results of the study can be concluded that there are various regulations on the protection of women and children that are referenced, but there is no law that specifically regulates the form of prevention and prevention of violence against women and children. The positive law that applies to prosecuting crimes and offences in the public sector is the Criminal Code. Among them are cases of bullyng between child abusers and child victims that have occurred in several districts / cities that have gone viral lately, until now there is no certainty of punishment in the form of clear education contained in the Child Protection Act.

KEYWORDS: Mechanism, Protection of Human Rights Law, Women and Children

\section{PENDAHULUAN}

Fenomena kekerasan terhadap perempuan dan anak akhir-akhir ini menjadi isu yang menonjol. Bukan saja hal itu disebabkan makin beratnya kasus kekerasan yang dialami perempuan dan anak, namun intensitasnya pun makin mengkhawatirkan. Untuk Indonesia, selain diperoleh dari pemberitaan media massa, peningkatan skala ruang, bentuk, intensitas, dan derajat kekerasan terhadap perempuan, juga diperoleh dari hasil penelitian yang semakin banyak dilakukan. ${ }^{1}$

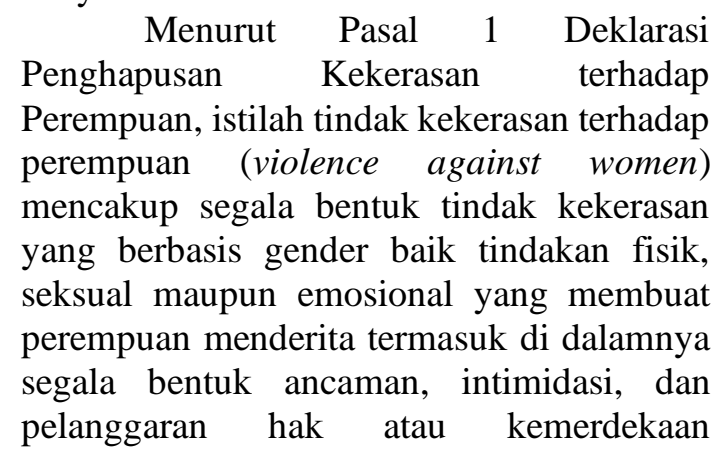

1 Anggun Lestari Suryamizon, 2017. Perlindungan Hukum Preventif Terhadap Kekerasan Perempuan Dan Anak Dalam perempuan baik secara terang-terangan maupun sembunyi-sembunyi.

Membicarakan masalah kekerasan terhadap perempuan, seakan-akan tidak ada pernah habisnya. Hampir setiap hari kita diberi sajian yang mengekspose kekerasan baik melalui media massa maupun mediamedia yang lainnya. Orang memukul, menganiaya, memperkosa bahkan membunuh hampir merupakan "santapan" wajib. Bahkan berita atau tayangan yang memuat peristiwa kriminal selalu menjadi headline, seakan-akan orang sudah memandang itu suatu yang biasa terjadi. Tindak kekerasan ini tidak hanya terjadi di luar lingkungan rumah, bahkan di dalam rumah yang seharusnya menjadi tempat yang paling aman bagi setiap anggota keluarga, kenyataannya bisa menjadi tempat yang menakutkan terutama bagi perempuan. Bila anggapan umum menyatakan tempat yang berbahaya adalah di luar rumah, bagi perempuan faktanya tampak tidak demikian. Perempuan justru lebih sering dilukai dan

Perspektif Hukum Hak Asasi Manusia. Marwah: Jurnal Perempuan, Agama dan Jender. Riau. No. 2. Vol 16:113. 
mengalami kekerasan dalam lingkup personal, baik dalam kaitan perannya sebagai istri, anak, anggota keluarga lain, pacar atau teman intim. ${ }^{2}$

Kekerasan sering terjadi terhadap perempuan dan anak, yang dapat merusak, berbahaya, dan menakutkan mereka. Perempuan dan anak yang menjadi korban kekerasan menderita kerugian, tidak saja bersifat material, tetapi juga bersifat immaterial seperti goncangan emosional dan psikologis, yang dapat memengaruhi kehidupan masa depan perempuan dan anak. Pelaku tindak kekerasan terhadap anak bisa saja orang tua (ayah dan atau ibu korban), anggota keluarga, masyarakat dan bahkan pemerintah sendiri (aparat penegak hukum dan lain-lain). ${ }^{3}$

Dalam kondisi apapun yang terjadi dalam masyarakat tidak lepas dari perempuan dan anak rentan terhadap bahaya (korban kejahatan). Perempuan dan anak menjadi korban perdagangan orang (trafficking), KDRT, ketenagakerjaan, komoditas seks, eksploitasi seksual, dan bentuk-bentuk kekerasan lainnya. Kekerasan yang berlangsung dan terjadi secara berulangulang merupakan situasi yang menyakitkan dan menekan seseorang yang mengalaminya. Setiap perbuatan yang menimbulkan tekanan, ancaman, tindakan kriminal termasuk dalam problematika sosial. Kondisi seperti ini amat sanga menyakitkan dan cenderung menimbulkan tekanantekanan yang berakibat pada terganggunya psikis seseorang. Seorang istri yang mengalami tindak kekerasan fisik maupun kekerasan seksual berdampak pada krisis psikologis yang semakin membuatnya tertekan dan tidak dapat percaya diri. Tidak hanya itu, kekerasan seksual menimbulkan penderitaan bagi seorang istri dimana ia akan kehilangan disfungsi seksual dan penyakit di daerah kewanitaan. ${ }^{4}$

Perlindungan terhadap perempuan dan anak rentan sebagai korban kejahatan

2 Dwi Hapsari Retnaningrum. 2009. Incest Sebagai Bentuk Manifestasi Kekerasan Terhadap Perempuan. Jurnal Dinamika Hukum. No.1. Vol 9:19

${ }^{3}$ Maidin Gultom, Perlindungan Hukum terhadap Anak dan Perempuan, Bandung: Refika Aditama, 2013, hal. 1-2. untuk menjadi perhatian yang sama pentingnya dengan pelaku dalam kejahatan. Bahwa dalam rangka menumbuhkan partisipasi masyarakat untuk mengungkap tindak pidana, perlu diciptakan iklim yang kondusif dengan cara memberikan perlindungan hukum dan keamanan kepada setiap orang yang mengetahui atau menemukan suatu hal yang dapat mengungkap suatu tindak pidana yang telah terjadi dan melaporkan hal tersebut kepada penegak hukum.

Adapun peran dari pemerintah (negara) dan instansi/lembaga pemerintah (Dinas Pemberdayaan Perempuan dan Perlindungan Anak Daerah Provinsi Sulawesi Utara) berkenaan dengan perlindungan hak asasi manusia (hukum) bagi perempuan dan anak rentan merupakan kewajiban dan bertanggung jawab untuk memberikan perlindungan sekaligus penanggulangan kepada perempuan dan anak baik kekerasan maupun korban kejahatan yang dialami baik secara fisik maupun mental.

Memperhatikan paparan di atas, penulis mengkaji mekanisme perlindungan Hukum HAM terhadap perempuan dan anak oleh Dinas Pemberdayaan Perempuan dan Perlindungan Anak Provinsi Sulawesi Utara, yang mencakup mekanisme perlindungan hak asasi manusia terhadap perempuan dan anak sebagai kelompok rentan serta kebijakan perlindungan, dan penanggulangan terhadap perempuan dan anak sebagai kelompok rentan dari kekerasan dan korban kejahatan.

\section{METODE PENELITIAN}

Metode penelitian yang digunakan adalah penelitian yuridis normatif yang bersifat kualitatif. Penelitian ini tercakup dalam tipe penelitian tentang norma atau hukum di dalam pelaksanaannya penelitian dalam tesis ini bila dikaitkan dengan judul

\footnotetext{
${ }^{4}$ Ayu Setyaningrum dan Ridwan Arifin. 2019. Analisis Upaya Perlindungan Dan Pemulihan Terhadap Korban Kekerasan Dalam Rumah Tangga (Kdrt) Khususnya Anak-Anak Dan Perempuan. Jurnal Ilmiah MUQODDIMAH. No 1. Vol 3:16.
} 
adalah bersifat kualitatif sebagaimana telah disinggung di atas. Tipe penulisan penelitian yuridis normatif adalah penelitian yang mengacu pada norma hukum yang terdapat pada peraturan perundang-undangan yang berlaku dan norma-norma yang hidup dan tumbuh berkembang dalam masyarakat. ${ }^{5}$

Penelitian ini bersifat kualitatif yaitu menganalisis secara mendalam dan holistik dengan mengkaji/menganalisis dari berbagai sudut pandang (komprehensif). ${ }^{6}$ Sifat mendalam dan holistik sebagai salah satu aspek pendekatan kualitatif (qualitative paradigm $)^{7}$ yang menekankan pada proses dan makna dari pelaku yang diteliti, serta realitas yang diteliti/terjadi. ${ }^{8}$ Data yang diperoleh dalam penulisan penelitian adalah sebagai pelengkap. ${ }^{9}$

Sumber data terdiri dari data primer dan data sekunder; (1) Sumber primer adalah data-data yang diperoleh melalui atau langsung dari sumbernya yakni instansi atau lembaga seperti Dinas Pemberdayaan Perempuan dan Perlindungan Anak Provinsi Sulawesi Utara dan instansi terkait lainnya. (2) Sumber sekunder adalah data yang diperoleh dari berbagai peraturan perundangundangan atau dokumen resmi, literatur/buku atau dalam ketentuan lain yang terbagi dalam dua yakni bahan hukum primer dan bahan hukum sekunder adalah bahan hukum yang mengikat seperti UUD NKRI 1945, UU Perlindungan Anak, UU PKDRT, UU HAM, KUHP, UU Peradilan Anak, Konvensi HakHak Anak, yang terkait dengan tulisan ini. Bahan hukum sekunder adalah sesuatu yang dapat memberikan penjelasan mengenai bahan hukum primer di atas seperti literatur/buku, jurnal hukum, artikel hukum, peraturan perundang-undangan, brosur, majalah hukum, makalah, sebagaimana terkait dengan bahan penulisan penelitian tesis ini dan tidak kalah pentingnya bahan hukum tersier, adalah segala sesuatu yang

5 Abdullah Sulaiman, Metode Penulisan Ilmu Hukum, Jakarta: YPPSDM, 2012, hal. 26.

6 Chai Podhisita, et. al, Theoritical Terminological and Philosophical Issues in Qualitative Research, Qualitative Research Methods. dapat memberi petunjuk terhadap bahan hukum primer dan sekunder (ensiklopedia, kamus hukum, dan sejenisnya).

Penelitian ini dilakukan melalui penelitian kepustakaan (library research), dengan mempelajari dan membaca literatur/buku-buku, jurnal, artikel, peraturan perundang-undangan, yurisprudensi, majalah hukum, brosur, koran dan bahan bacaan lainnya yang erat hubungannya dengan topik penulisan penelitian di atas dalam rangka untuk memperoleh landasan teoritis sebagai dasar dalam melakukan penelitian. Penelitian lapangan (field research) adalah penelitian yang dilakukan dengan mengumpulkan datadata langsung dari pihak yang berkompeten sebagaimana dilakukan oleh para peneliti pada umumnya, sesuai apa yang diharapkan.

Data yang telah terkumpul dianalisis melalui dua tahap. Tahap pertama menggunakan strategi analisis umum yang disebut strategi menggandakan proposisiproposisi teoritis (relying on theoretical prepositions), dan pada tahap berikutnya menggunakan teknik analisis yang disebut dengan explanation building. Strategi analisis umum dengan mengandalkan proposisi-proposisi teoritis adalah analisis data dengan cara mengikuti proposisiproposisi yang menuntun seluruh rangkaian studi. Proposisi-proposisi dilakukan untuk memfokuskan perhatian pada data tertentu dan mengabaikan data yang lain, dan membantu mengorganisasi keseluruhan studi serta mendefinisikan penjelasan alternatif untuk diuji. Adapun teknik analisis explanation building digunakan karena model analisis ini dibutuhkan untuk menjelaskan suatu rangkaian hubungan kausal tentang fenomena atau kasus tertentu, yang bersifat kompleks dan sulit diukur secara pasti, sehingga dapat ditarik suatu kesimpulan yang dapat dipertanggungjawabkan secara ilmiah

${ }^{7}$ Kenneth D. Bailey, Methods of Social Research, New York: The Free Press, 1982, hal. 62.

${ }^{8}$ Robert K. Yin, Applications of Case Study Research, Thousand Oaks: Sage Publications, 2011, hal. 4.

9 L.A. Suparman, Statistik Sosial, Jakarta: Rajawali, 1992, hal. 1. 
sebagai upaya untuk menjawab atau memecahkan permasalahan.

\section{HASIL DAN PEMBAHASAN}

\section{Mekanisme Perlindungan Hak Asasi Manusia Terhadap Perempuan dan Anak sebagai Kelompok Rentan}

Mekanisme perlindungan HAM terhadap perempuan dan anak pada Dinas Pemberdayaan Perempuan dan Perlindungan Anak mengacu pada peraturan perundangundangan yang berlaku di Indonesia. Kemudian dijabarkan melalui peraturan daerah maupun peraturan gubernur diantaranya Peraturan Daerah Sulawesi Utara Nomor 21 Tahun 2004 tentang Tindak Pidana Perdagangan Orang yang saat ini dalam tahap revisi serta Peraturan-Peraturan Gubernur diantaranya pembentukan Satuan Tugas Perlindungan Perempuan dan Anak.

Dalam rangka memaksimalkan mekanisme penanganan kasus perempuan dan anak korban kekerasan maka pemerintah provinsi Sulawesi Utara membentuk Unit Pelaksana Teknis Daerah Perlindungan Perempuan dan Anak Provinsi Sulawesi Utara dengan Peraturan Gubernur Nomor 32 tahun 2020.

Alur penanganan kasus perempuan dan anak korban kekerasan di Unit Pelaksanaan Teknis Daerah Perlindungan Perempuan dan Anak (UPTD PPA) terdiri dari:

\section{Pengaduan}

Korban/pelapor dapat mendatangi UPTD PPA untuk membuat laporan ataupun bisa secara online melalui hotline maupun meng unduh aplikasi LAKER pada google playstore. Kasus yang diadukan akan diidentifikasi oleh petugas pengaduan untuk menganalisa kebutuhan korban.

2. Tindaklanjut

Kasus yang telah diidentifikasi kemudian diberikan layanan sesuai kebutuhan korban. Adapun jenis layanan yang ada di UPTD PPA adalah layanan kesehatan (dokter), layanan Psikolog, layanan rohaniawan, layanan bantuan hukum (advokad) dan rumah aman (shelter). Khusus bagi anak baik korban maupun pelaku dilakukan sesuai dengan Sistem Peradilan Pidana Anak dimana mengedepankan kepentingan terbaik bagi anak, perlindungan keadilan, nondiskriminasi, penghargaan terhadap anak, kelangsungan hidup dan tumbuh kembang anak, proporsional, perampasan kemerdekaan yang tertuang dalam amandemen UUD 1945 BAB XA Pasal 28A-28J

UPTD PPA sebagai unit layanan teknis yang menyelenggarakan layanan perlindungan terhadap perempuan dan anak menjalankan fungsi menerima pengaduan masyarakat, menjangkau korban, menyediakan tempat penampungan sementara, memberikan mediasi dan mendampingi korban. UPTD PPA menyediakan layanan medis oleh dokter, konsultasi dan pendampingan psikolog, konsultasi dan bantuan hukum, konsultan gender, pendampingan oleh terapis, rumah aman, ruang bermain anak, bimbingan rohani dan kunjungan rumah.

Selain itu, untuk mempermudah masyarakat dan memberikan pelayanan yang efektif dan efisien, UPTD PPA hadir ditengah-tengah masyarakat dengan menyediakan layanan pengaduan secara online lewat aplikasi LAKER yang dapat di unduh pada Google Playstore serta hotline 081243441300 dan 082292222267. Semua jenis layanan dapat dinikmati oleh masyarakat secara gratis. UPTD PPA juga sudah berjejaring dengan unit-unit layanan seperti Kepolisian, Rumah Sakit, Puskesmas serta lembaga-lembaga layanan yang dibentuk oleh masyarakat.

Namun dalam prakteknya antara Lembaga-Lembaga Layanan Pemerhati Perempuan dan Anak belum melakukan sinkronisasi secara maksimal dengan Dinas Pemberdayaan dan Perlindungan Perempuan dan Anak Daerah Provinsi Sulawesi Utara dalam hal ini Unit Pelaksana Teknis Daerah Perlindungan Perempuan dan Anak. Mekanisme perlindungan terhadap perempuan masih dilakukan sendiri-sendiri tanpa melibatkan Pemerintah. Ini menjadi tantangan bagi Dinas Pemberdayaan dan Perlindungan Perempuan dan Anak Daerah Provinsi Sulawesi Utara untuk dapat menjalin kerjasama dengan jejaring-jejaring 
yang ada untuk lebih memaksimalkan perlindungan terhadap perempuan dan anak.

Selain itu, belum adanya MoU bersama stakeholder terkait diantaranya Dinas Kesehatan dimana berhubungan dengan kesehatan korban baik lewat Puskesmas maupun Rumah Sakit Pemerintah, Dinas Pendidikan bias membantu korban yang bermasalah dengan pendidikan, Dinas Ketenagakerjaan bagi korban yang mendapatkan kekerasan di tempat kerja, Dinas Sosial khusus untuk penyediaan Rumah Aman serta pemberian keterampilan bagi korban sehingga korban siap untuk dikembalikan ke lingkungannya. Apabila kerjasama antar stakeholder sudah berjalan dengan baik maka penanganan terhadap korban kekerasan baik perempuan maupun anak akan lebih maksimal.

Mekanisme perlindungan hak asasi manusia bagi kelompok rentan yang mana mekanisme hak asasi manusia diartikan sebagai sistem, yang dengan sistem ini dilakukan upaya pemajuan dan perlindungan hak asasi manusia. Sasaran pemajuan dan perlindungan hak asasi manusia tersebut dapat berupa semua orang secara umum dan menyeluruh atau orang-orang tertentu, yang karena kekhususannya, terutama sebagai akibat kerentanannya, memerlukan perhatian dan perlindungan yang lebih daripada orang lain, seperti anak, perempuan, orang dengan disabilitas, pekerja migran, masyarakat hukum adat atau masyarakat terpencil, kelompok minoritas, orang-orang yang berorientasi seksual atau beridentitas gender tertentu. ${ }^{10}$

Mekanisme regional demikian terdapat di kawasan Afrika, Eropa, dan Kawasan Amerika. Di Asia tidak terdapat mekanisme regional bagi pemajuan dan perlindungan hak asasi manusia sebagaimana yang terdapat di tiga kawasan lain tersebut di depan khususnya pada perlindungan perempuan dan anak.

10 Muladi, Demokratisasi, Hak Asasi Manusia, dan Reformasi Hukum Indonesia, cet.1, Jakarta: The Habibie Center, 2002, hal. 56

${ }^{11}$ Knut D. Asplund, Suparman Marzuki, Eko Riyadi, Hukum Hak Asasi Manusia, Yogyakarta: PUSHAM UII, 2008, hal. 231-232.
Mekanisme pemajuan dan perlindungan hak asasi manusia di tataran internasional tidak hanya terbatas pada badan-badan sebagaimana dimaksud tersebut, melainkan juga seperti pembinaan kemitraan atau pelibatan organisasiorganisasi masyarakat sipil dalam pemajuan dan perlindungan hak asasi manusia yang dilakukan oleh badan-badan pemajuan dan perlindungan hak asasi manusia yang dibentuk berdasarkan instrumen internasional hak asasi manusia yang bersangkutan. ${ }^{11}$

Kebijakan Perlindungan Hak Asasi Manusia Terhadap Perempuan dan Anak sebagai Kelompok Rentan

\section{Lahirnya UU PKDRT}

dilatarbelakangi oleh perkembangan dewasa ini yang menunjukkan bahwa tindak kekerasan dalam rumah tangga pada kenyataannya sering terjadi dalam kehidupan masyarakat, baik dalam bentuk kekerasan fisik, psikis, seksual maupun penelantaran rumah tangga. Harapan UU PKDRT adalah masyarakat luas lebih bisa melaksanakan hak dan kewajibannya dalam lingkup rumah tangganya sesuai dengan dasar agama yang dianutnya. Penegak hukum dan aparat terkait dalam penanganan korban kekerasan dalam rumah tangga akan lebih sensitif dan responsif terhadap penanganan kasus-kasus kekerasan dalam rumah tangga untuk pencegahan dan perlindungan. ${ }^{12}$

Keadaan di mana hukum tidak dapat menjangkau perempuan di wilayah domestik, menyebabkan perempuan rentan terhadap tindak kekerasan dalam rumah tangga. Pengertian dari kekerasan rumah tangga sering kali menimbulkan kebingungan. Istilah kekerasan dalam rumah tangga, kekerasan keluarga, pelecehan suami, pelecehan istri, penyerangan terhadap istri, semuanya seringkali diartikan sama.

12 I. Marsana Windhu, Kekerasan terhadap Anak, Pusat Kajian dan Perlindungan Anak, 1999, hal. 70-71. 
Dalam definisi ini tidak mengklasifikasikan perbuatan perkosaan dalam ikatan perkawinan (suami terhadap istri) sebagai kejahatan. Perkosaan oleh suami terhadap istri (marital rape) sampai saat ini belum dianggap sebagai kejahatan. Dalam KUHP, kasus-kasus yang tergolong kekerasan terhadap perempuan memang dapat dijaring dengan pasal-pasal kejahatan namun terbatas pada tindak pidana umum (korban laki-laki maupun perempuan). Seperti misalnya kesusilaan, perkosaan, penganiayaan, pembunuhan, dan lain-lain.

Untuk penyelesaiannya sendiri di pengadilan, biasanya tidaklah memberikan jaminan bahwa tidak akan terulangnya kekerasan terhadap perempuan dalam rumah tangga. Pengadilan cenderung meminta pasangan tersebut untuk kembali berbaikan. Kalau istri mau menerima kembali suaminya, maka kasus tersebut akan diberhentikan dan persoalan dianggap selesai.

Hukum positif di Indonesia memiliki banyak keterbatasan untuk menindak kekerasan dalam rumah tangga. Keterbatasan tersebut dapat dilihat bahwa hukuman yang dijatuhkan untuk pelaku perbuatan ini biasanya lebih ringan dibandingkan kejahatan lainnya. Proses hukum membutuhkan waktu yang panjang, padahal di sisi yang lain perempuan korban kekerasan dalam rumah tangga segera membutuhkan perlindungan.

Peranan aparat penegak hukum dalam hal ini adalah polisi pun belum maksimal. Polisi seringkali tidak cukup peka untuk menggunakan pasal-pasal yang ada dalam KUHP untuk menyeret pelaku kekerasan terhadap perempuan ke pengadilan. Implikasinya perempuan kemudian menjadi enggan untuk melaporkan penyerangan yang dialaminya kepada polisi karena polisi tidak melakukan tindakan apaapa. Polisi seringkali meyakinkan perempuan untuk melakukan rekonsiliasi, bukan melakukan penuntutan. Beberapa alasan yang dapat ditarik adalah: ${ }^{13}$ (1) Polisi menganggap bahwa kekerasan terhadap perempuan itu terjadi karena perempuan yang

${ }^{13}$ Dede Kania. 2015. Hak Asasi Perempuan dalam Peraturan Perundang-Undangan Di Indonesia. Jurnal Konstitusi, No. 4. Vol 12:718 memancing terjadinya kekerasan atau karena perempuan yang bersangkutan melakukan perbuatan yang pantas dihukum dengan pemukulan. (2) Polisi menganggap bahwa kekerasan dalam rumah tangga itu adalah persoalan pribadi dan harus diselesaikan di dalam rumah.

Penanggulangan dan pencegahan terhadap kekerasan dalam rumah tangga, pemerintah berkewajiban dan berupaya:

1. Kewajiban Pemerintah: (a) Merumuskan kebijakan penghapusan kekerasan dalam rumah tangga; (b) Menyelenggarakan advokasi dan sosialisasi; (c) Menyelenggarakan pendidikan dan pelatihan sensitif gender serta menetapkan standar akreditasi pelayanan yang sensitif gender. ${ }^{14}$ Upaya penyelenggaraan layanan adalah: (a) Penyediaan ruang layanan khusus di kantor kepolisian; (b) Penyediaan aparat, tenaga kesehatan, pekerja sosial, dan pembimbing rohani; (c) Pembuatan dan pengembangan sistem mekanisme program pelayanan kerja sama; (d) Memberikan perlindungan bagi pendamping, saksi, keluarga, dan teman korban. ${ }^{15}$

2. Kewajiban Masyarakat

Kewajiban masyarakat adalah untuk menyelenggarakan upaya-upaya pemerintah dan/atau pemerintah daerah masing-masing dapat bekerja sama dengan masyarakat atau lembaga sosial lainnya. Setiap orang yang mendengar, melihat atau mengetahui terjadi kekerasan dalam rumah tangga wajib: 1) mencegah berlangsungnya tindak pidana; 2) memberikan perlindungan kepada korban; 3) memberikan pertolongan darurat; 4) membantu proses pengajuan permohonan penetapan perlindungan. ${ }^{16}$

3. Peran Kepolisian

Kepolisian berperan dalam memberikan perlindungan: 1) sejak diketahui atau diterimanya laporan KDRT dalam waktu 1 x 24 jam kepolisian wajib segera memberikan perlindungan sementara pada korban; 2) perlindungan sementara diberikan paling lama 7 (tujuh) hari sejak

\footnotetext{
14 Pasal 11 dan Pasal 12 UU PKDRT.

15 Pasal 13 UU PKDRT.

${ }^{16}$ Pasal 15 UU PKDRT.
} 
diterima atau ditangani; 3) dalam waktu 1 x 24 jam sejak pemberian perlindungan sementara kepolisian wajib meminta surat penetapan perintah perlindungan dari pengadilan. Kepolisian dapat bekerja sama dengan tenaga kesehatan, pekerja sosial, relawan pendamping dan/atau pembimbing rohani. Kepolisian segera menyampaikan kepada korban tentang identitas petugas, kekerasan dalam rumah tangga adalah kejahatan terhadap martabat kemanusiaan, kewajiban kepolisian untuk melindungi korban. ${ }^{17}$

4. Peran Tenaga Kesehatan

Dalam memberikan pelayanan kesehatan kepada korban, tenaga kesehatan harus memeriksa kesehatan korban sesuai standar profesinya dan membuat laporan tertulis tentang hasil/pemeriksaan korban dan visum et repertum. Tenaga kesehatan juga memberikan pelayanan kesehatan yang dilakukan di sarana kesehatan milik pemerintah, pemerintah daerah atau masyarakat. Tenaga kesehatan memulihkan dan merehabilitasi kesehatan korban. ${ }^{18}$

5. Peran Pekerja Sosial

Dalam memberikan pelayanan, pekerja sosial harus: 1) melakukan konseling; 2) memberikan informasi tentang hak-hak korban; 3) mengantar korban ke rumah aman atau tempat tinggal alternatif; 4) melakukan koordinasi terpadu dengan kepolisian, dinas sosial, lembaga sosial yang dibutuhkan korban. Pelayanan pekerja sosial dilakukan di rumah aman milik pemerintah, pemda atau masyarakat. 19

6. Peran Advokat

Dalam memberikan pelayanan, advokat wajib: (a) Memberikan konsultasi hukum; (b) Mendampingi korban dalam proses hukum; (c) Melakukan koordinasi dengan sesama penegak hukum, relawan pendamping, dan pekerja sosial. ${ }^{20}$

Adapun hal-hal dan pemulihan korban untuk melaporkan kekerasan dalam rumah tangga, korban berhak melapor secara langsung kekerasan dalam rumah tangga kepada kepolisian di tempat korban atau di tempat kejadian; Korban dapat memberikan kuasa kepada keluarga atau orang lain untuk melaporkan kekerasan dalam rumah tangga. ${ }^{21}$ Dalam hal korban adalah seorang anak, laporan dapat dilakukan oleh orang tua, wali, pengasuh, untuk anak yang bersangkutan. ${ }^{22}$

Hak-hak korban adalah perlindungan dari keluarga, kepolisian, kejaksaan, pengadilan, advokat, lembaga sosial atau pihak lain, baik sementara atau berdasarkan perintah perlindungan dari pengadilan; pelayanan kesehatan sesuai kebutuhan medis; pelayanan khusus terkait kerahasiaan korban; pendampingan atau pekerja sosial dan bantuan hukum dan pelayanan bimbingan rohani. Terhadap korban dilakukan perlindungan, di mana Ketua Pengadilan dalam waktu 7 (tujuh) hari sejak diterimanya permohonan surat penetapan berisi perintah perlindungan wajib dikeluarkan oleh Ketua Pengadilan. ${ }^{23}$ Permohonan surat perintah perlindungan dapat diajukan oleh korban atau keluarga korban, teman korban, kepolisian, relawan pendamping atau pembimbing rohani. ${ }^{24}$ Disampaikan dalam bentuk lisan atau tertulis; panitera pengadilan wajib mencatatnya; dalam permohonan diajukan oleh keluarga, kepolisian, relawan pendamping, pembimbing rohani harus persetujuan korban. Dalam hal tertentu, permohonan dapat diajukan tanpa persetujuan korban. ${ }^{25}$

Terhadap korban dilakukan pemulihan: untuk kepentingan pemulihan, korban dapat memperoleh pelayanan dari tenaga kesehatan, pekerja sosial, relawan pendamping, dan/atau pembimbing rohani. ${ }^{26}$ Pekerja sosial, relawan pendamping, dan/atau pembimbing rohani wajib memberikan pelayanan kepada korban dalam bentuk pemberian konseling untuk menguatkan dan/atau memberikan rasa aman bagi

\footnotetext{
${ }^{22}$ Pasal 27 UU PKDRT.

${ }^{23}$ Pasal 28 UU PKDRT.

${ }^{24}$ Pasal 29 UU PKDRT.

${ }^{25}$ Pasal 30 UU PKDRT.

${ }^{26}$ Pasal 39 UU PKDRT.
} 
korban. ${ }^{27}$ Dalam rangka pemulihan terhadap korban, tenaga kesehatan, pekerja sosial, relawan pendamping, dan/atau pembimbing rohani dapat melakukan kerja sama.

Dalam hukum pidana positif yang berlaku, kerugian yang dialami anak sebagai korban tindak kekerasan belum secara konkret diatur. Artinya hukum pidana positif memberikan perlindungan kepada anak sebagai korban, lebih banyak merupakan perlindungan abstrak atau perlindungan tidak langsung, yaitu dengan adanya berbagai perumusan tindak pidana dalam perundangundangan. Sistem sanksi dan pertanggungjawaban pidana tidak tertuju pada perlindungan korban secara langsung dan konkret, tetapi hanya perlindungan korban secara tidak langsung dan abstrak. Diantaranya kasus bullyng antara pelaku anak dan korban anak yang terjadi dibeberapa kabupaten/kota di Sulawesi Utara yang viral akhir-akhir ini, sampai saat ini belum ada kepastian hukuman dalam bentuk edukasi yang jelas yang tertuang dalam UndangUndang Perlindungan Anak. ${ }^{28}$

Adapun bentuk dan sebab kekerasan bahwa bentuk-bentuk kekerasan yang dialami anak dan perempuan, yaitu dalam bentuk pelecehan seksual berupa pencabulan atau perkosaan, trafficking atau perdagangan anak dan perempuan, pembunuhan, pembacokan atau pemukulan. Peristiwaperistiwa tersebut hanya merupakan bagian kecil tindak kekerasan yang terjadi. Dari peristiwa-peristiwa tersebut dapat diketahui pelaku tindak kekerasan terhadap anak bukan saja orang yang tidak dikenal korban, akan tetapi juga pelaku yang dikenal korban dan mempunyai hubungan darah dengan korban atau dengan kata lain pelaku merupakan salah satu anggota keluarga korban sendiri. ${ }^{29}$

\section{PENUTUP}

Peraturan-peraturan Pemerintah Pusat dijalankan oleh Pemerintah Daerah dalam hal ini Dinas Pemberdayaan Perempuan dan Perlindungan Anak Daerah melalui Unit Pelaksana Teknis Daerah Provinsi Sulawesi Utara dalam mekanisme

\footnotetext{
27 Pasal 41 UU PKDRT.

${ }^{28}$ Barda Nawawi Arief, Beberapa Aspek Kebijakan Penegakan dan Pengembangan
}

perlindungan hukum dengan menjabarkan dalam aturan-aturan daerah serta bekerjasama dengan berbagai pihak seperti kepolisian, kejaksaan, pengadilan, lembagalembaga Masyarakat Pemerhati Perempuan dan Anak serta lembaga-lembaga Pemerintah yang berwenang dalam perlindungan perempuan dan anak dari tindak kekerasan. Namun dalam prakteknya antara lembagalembaga Masyarakat Pemerhati Perempuan dan Anak belum bersinergi secara maksimal dengan Dinas Pemberdayaan Perempuan dan perlindungan Anak Daerah Provinsi Sulawesi Utara, ini dapat dilihat dalam penanganan kasus yang sempat menjadi viral pada bulan Februari dimana seorang oknum anggota dewan menjalin hubungan terlarang dengan seorang perempuan yang baru beranjak dewasa, dimana masing-masing lembaga melakukan penanganan secara individu tanpa melibatkan lembaga Pemerintah. Selain itu belum ada Mou antara stakeholder terkait dengan Dinas Pemberdayaan Perempuan dan Perlindungan Anak Daerah Provinsi Sulawesi Utara.

Berbagai regulasi tentang perlindungan perempuan dan anak yang menjadi acuan bagi Unit Pelaksana Teknis Daerah Provinsi Sulawesi Utara dalam memberikan perlindungan terhadap perempuan dan anak korban kekerasan, namun sejauh ini belum ada hukum yang secara khusus mengatur bentuk pencegahan dan penanggulangan tindak kekerasan terhadap perempuan dan anak. Hukum positif yang berlaku untuk menuntut kejahatan dan pelanggaran di sektor publik adalah KUHP. Diantaranya kasus bullyng antara pelaku anak dan korban anak yang tejadi dibeberapa kabupaten/kota yang viral akhir-akhir ini, sampai saat ini belum ada kepastian hukuman dalam bentuk edukasi yang jelas yang tertuang dalam Undang-Undang Perlindungan Anak.

Melalui pengaturan mekanisme pemajuan dan perlindungan hak asasi manusia, diharapkan para korban memahami hak-haknya dan prosedur pemenuhannya. Serta bagi pemerintah, penegak hukum,

Hukum Pidana, Bandung: Citra Aditya Bakti, 1998, hal. 54-55.

${ }^{29}$ Ibid hal. 96. 
lembaga masyarakat pemerhati perempuan dan anak dan pihak terkait lainnya agar proporsional dan professional dalam melaksanakan peraturan perundangundangan sehingga terpenuhinya perlindungan secara baik, cepat, objektif, transparan dan akuntabel. Membuat MoU dengan stakeholder terkait mengenai penanganan terhadap perempuan dan anak korban kekerasan dalam bentuk Rencana Aksi Daerah (RAD) yang berisi siapa berbuat apa. Perlu adanya penguatan regulasi khusus yang mengatur bentuk pencegahan dan penanggulangan tindak kekerasan terhadap perempuan dan anak, idealnya seimbang dengan ketentuan terkait perempuan dan anak korban kekerasan serta keterkaitan dengan aturan-aturan lain jangan sampai tumpeng tindih atau bahkan sulit diaplikasikan.

\section{DAFTAR PUSTAKA}

Anggun Lestari Suryamizon, 2017. Perlindungan Hukum Preventif Terhadap Kekerasan Perempuan Dan Anak Dalam Perspektif Hukum Hak Asasi Manusia. Marwah: Jurnal Perempuan, Agama dan Jender. Riau. No. 2. Vol 16:113.

Dwi Hapsari Retnaningrum. 2009. Incest Sebagai Bentuk Manifestasi Kekerasan Terhadap Perempuan. Jurnal Dinamika Hukum. No.1. Vol 9:19

Maidin Gultom. 2013 Perlindungan Hukum terhadap Anak dan Perempuan, Bandung: Refika Aditama.

Ayu Setyaningrum dan Ridwan Arifin. 2019. Analisis Upaya Perlindungan Dan Pemulihan Terhadap Korban Kekerasan Dalam Rumah Tangga (Kdrt) Khususnya Anak-Anak Dan Perempuan. Jurnal Ilmiah MUQODDIMAH. No 1. Vol 3:16.

Abdullah Sulaiman, 2012. Metode Penulisan Ilmu Hukum, Jakarta: YPPSDM.

Chai Podhisita, et. Al. 1982. Theoritical Terminological and Philosophical Issues in Qualitative Research, Qualitative Research Methods. Kenneth D. Bailey, Methods of
Social Research, New York: The Free Press.

Robert K. Yin. 2011. Applications of Case Study Research, Thousand Oaks: Sage Publications.

L.A. Suparman. 1992. Statistik Sosial, Jakarta: Rajawali.

Rianto Adi. 2010. Metodologi Penelitian Sosial dan Hukum, Jakarta: Granit.

Soerjono Soekanto dan Sri Mamudji. 2015. Penelitian Hukum Normatif Suatu Tinjauan Singkat, Jakarta: Rajawali.

Soerjono Soekanto. 2006. Pengantar Penelitian Hukum, Jakarta: UI Press.

Ronny Hanitijo Soemitro. 1990. Metodologi Penelitian Hukum dan Jurimetri, Cet. V, Jakarta: Ghalia Indonesia.

Peter Mahmud Marzuki. 2005. Penelitian Hukum, Jakarta: Prenada Media.

Muladi. 2002. Demokratisasi, Hak Asasi Manusia, dan Reformasi Hukum Indonesia, cet.1, Jakarta: The Habibie Center.

Knut D. Asplund. 2008. Suparman Marzuki, Eko Riyadi, Hukum Hak Asasi Manusia, Yogyakarta: PUSHAM UII.

I. Marsana Windhu. 1999. Kekerasan terhadap Anak, Pusat Kajian dan Perlindungan Anak.

Dede Kania. 2015. Hak Asasi Perempuan dalam Peraturan PerundangUndangan Di Indonesia. Jurnal Konstitusi, No. 4. Vol 12:718

Barda Nawawi Arief. 1998. Beberapa Aspek Kebijakan Penegakan dan Pengembangan Hukum Pidana, Bandung: Citra Aditya Bakti. 